\title{
Role of Imparting Value Driven Soft Skills in Young Managers: An Empirical Study in The Indian Context
}

Effulgence

Vol. 15 No. 2

July-December, 2017

Rukmini Devi Institute of Advanced Studies

E-mail : effulgence@rdias.ac.in, Website : www.rdias.ac.in http://effulgence.rdias.ac.in/user/default.aspx https://dx.doi.org/10.33601/effulgence.rdias/v15/i2/2017/44-51

\author{
Prof. Shalini Garg ${ }^{1}$ \\ Shipra Sharma ${ }^{2}$
}

\begin{abstract}
The institutes are in constant pressure from the organizations to train students in a way that they are best fit for organizations. These educational institutes often rigor themselves by upgrading curricula as well as pedagogy so as to impart best managerial and technical skills to the students. Looking at today's scenario although students have technical skills but they generally lacks in soft skills which are essential for achieving peak performance in organizations and becoming good managers.

Therefore, this paper tries to investigate influence factors (Teachers and Institutes) in imparting value driven soft skills to these budding managers. It also tries to demonstrate $4 C^{\prime}$ s (Collaboration, Creativity, Communication and Critical Thinking) imparting Values to enhance the performance of young managers in organizations.
\end{abstract}

Keywords: Schwartz Value Theory, Value based Pedagogy, value drive soft skills.

\section{INTRODUCTION}

$\mathrm{F}$ rom many decades the field of management education is regularly under strain from organizations to prepare the students in a way that they are employable and contribute their skills to the organization and society as a whole. Today when there is immense competition in every field, organizations are too striving for finding a potential employee. Progressive companies are committed to build and maintain high quality teams. These organizations are demanding the institutions to understand the cultural dynamics within the organizations and make young managers fit for high quality team work in order to achieve organizational performance. Thereby organizations insist B-schools to make changes in their pedagogy so as to match up with the requirements of companies.

However, the business world is constantly suffering from unethical issues; this again brings B-Schools under deep thrift to impart pedagogy rich in delivering value to young minds. Institutions are trying to make young manager's market ready by delivering value driven soft skills and thus helping

1. Professor, University of School of Management Studies, GGSIP University, New Delhi, shalinivineet@yahoo.com

2. Research Scholar, University of School of Management Studies, GGSIP University, New Delhi, shiprasharma_1@rediffmail.com 
them to achieve peak performance while at work.

The paper is based on ten human values proposed by Schwartz's Value theory which acts as essential soft skills for today's young leaders. These ten basic personal values have been recognized by Schwartz's value survey and portrait values questionnaire on the basis of responses collected from 82 countries. The findings of Schwartz's value theory reveal that there exists substantial difference in value priorities by individuals. These values are Self Direction, Stimulation, Hedonism, Achievement, Power, Security, Conformity, Tradition, Benevolence, and Universalism which leads young managers to develop four C's (Collaboration, Creativity, Critical Thinking and Communication) (Alan D., Greenberg, Andrew H. N. 2014) which are mandatory soft skills for a good manager to perform in the organization.

\section{Schwartz's Value Theory Driving Soft Skills}

Seetha, S. soft skills are essential people's skill; four C's are stated to be vital soft skills for building good managers. When these skills are enriched with values it modulates the personality, attitude and behavior of an individual.

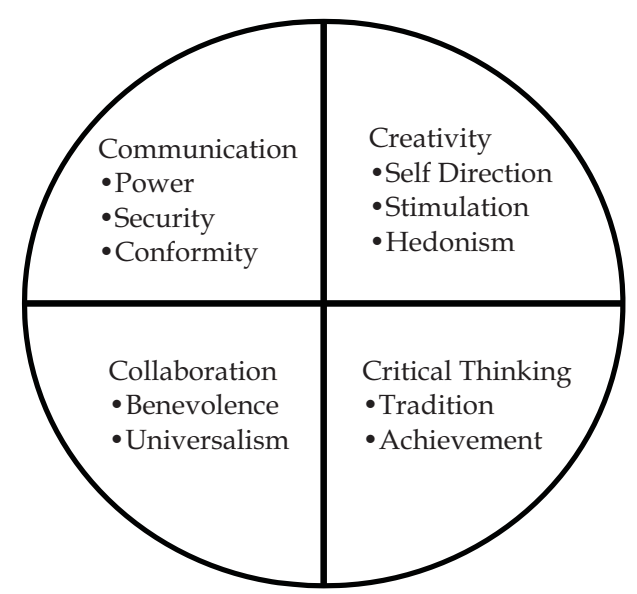

Figure 1: Soft Skills Driven from Schwartz's Value Theory

These Successive values can have the close relationship with four C's:
Creativity: Self Direction, Stimulation, Hedonism

Communication: Power, Security, Conformity

Critical Thinking: Tradition, Achievement

Collaboration: Benevolence, Universalism

According to figure 1, each " $\mathrm{C}$ " comprises of certain set of values which can be essential for today's budding leaders. Creativity can be referred as generation of ideas which helps in stimulating ones brain and making oneself open to adapt the dynamic environment. Teachers, institutes and family environment play a very vital role in building the personality of a student. Teachers and family needs to understand the efficiency of young talents and provide them with open atmosphere to discover new ventures and guiding them in a right direction whenever required. This helps in building their analytical skills, problem solving skills; thereby making them self directed and feel the pleasure in whatever work they do.

Another " $\mathrm{C}$ " mostly required and looked forward by recruiters is Communication. As per NEA (National Education association) communication is the art to inform, construct, motivate and persuade an individual. It reflects ones attitude, behavior and values. The way one communicates indicates the authority in speech (power), the clarity in speech (conformity) and the sense of stability and security in action. The teachers at various management institutes have a social responsibility of training students in a way that imparts such values to make them good performers and successful leaders.

One cannot learn well without thinking well and therefore, Critical Thinking is an essential requirement for budding managers. Critical thinking is referred as logical arrangement of ideas which is greatly influenced by our traditions, beliefs. Traditions and beliefs are learned by an individual through their parents and surroundings. Over a course of time we normally experience, develops perceptual possessions and other prejudices which are considered as barriers to effective communication. Teachers and parents have a great 
responsibility of nurturing these young minds in a way that they do not develop negative possessions and increase the inefficiency of decision. A clear and logical thought increase the occurrence of achieving a set target; thereby giving a sense of achievement to young leaders.

Today a great emphasis is laid on fourth " $\mathrm{C}$ " which is Collaboration. The importance of collaboration is not only seen by organizations but has also been experienced by these management institutes. Organizations look for team work and thus pressurize the institutes to lay emphasis on developing the skills to work effectively and respectfully with diverse teams. Thus, these institutes try to impart team building skills through their curriculum.

\section{LITERATURE REVIEW}

People who become great statesmen, successful business entrepreneurs, have something in common. They always strive to give their best for the benefit of the society. But looking at the recent crisis it is believed that the youth is getting deprived of values. Knowledge without values is not only useless but can be dangerous (Jindal, J. 2013). When knowledge is applied in a right direction as per the society norms they are said to be productive to global economy. But when the same knowledge is applied for achieving self motives and unethical gratifications it becomes harmful for the society and increases crime. Crime is basically defined as something which is forbidden by law and is punishable. Crime is committed due to a criminal behavior in oneself which depends on individual, societal and ecological factors that are developed over a course of our lives (Richerson, P.J. 1991). Many young minds are driven by delinquencies and thus get involved in crimes like drug abuse, money laundering, sexual assault, corruption and many more. This normally occurs due to unemployment or low income to these young minds which get swayed away with the charms of criminal world and gets involved in it. $13^{\text {th }}$ United Nations Crime Congress is exploring the ways crime can be prevented; it states that crime prevention and justice can be brought to the society by eradicating poverty, and increasing access to health, education, water and energy. As criminal violence is taking a rising toll, [United Nations New Centre] UN report finds the causes of recent increase in crime including social, economic and global issues can be prevented through education.

It can be depicted by UN report the solution to this crisis can be value education. Over past some many years colleges and institutes are slogging their energy and resources to impart education reach in values to meet the issues of respective countries. Countries like India, Australia and Singapore lay a strong emphasis on imparting value education through well defined curricula and syllabi (Singh, A. 2011).Various researches have taken place which attempts to analyze the impact of value education on academic performance. Thereby, attempts to build young and dynamic managers.

Keeping in mind behavioral delinquencies and imparting value drive soft skills it becomes important to train teachers who are acting as an agent for social change (Seshadri, C. 2005). Cubakcu, F. 2013 Schools are not value free or Value neutral zones but plays a very vital role in shaping ones character. According to Black, W. we sow an act and reap a habit; we sow a habit and reap a character; we sow a character and reap a destiny.

An individual behavior is influenced by its surroundings, they first comes in contact with their parents, teachers, friends (society) and climate at the schools, colleges, university. Fyffe, L.R. 2006 explores the characteristics possessed by children who gain high scores on the Children's Values Profile compared with children who gain low scores on the instrument. (Sharma, S., Garg, S., Mittal, S. 2015) develop a conceptual model for imparting values in young generations that involves parents, teachers, society and university. The course curriculum reach in moral teachings can modify the behavior of these 
young minds. (Choudhuri, I. 2005) Traditional literature of ancient India fabricates values in a way that the gap between art and religion is reduced. Young individuals enjoy reading literature in the form of short stories and in the process they become aware of cultural ethos and values.

The environment in the institute also helps these youngsters to develop positive possessions. These institutes' plays a very vital role in imparting value driven education. Value education does not mean value imposition or indoctrination. It helps to develop and demonstrate proper attitude, feelings and behavior patterns at different situations (Reddy, G.L., Thankachan, T.C, Shailaja, M. 2013). If we compare the value system of the modern society to the prehistoric India we will find the huge difference (Srivastava, A. 2013). In prehistoric phase an individual was educated through Upanishads, Vedas, and other literature sculptures, which kept these individuals physically, emotionally and ecologically attached to the cultural ethos of the society.

Even parents play a vital role in shaping the character of a child. The first acquaintance of child since birth happens with his or her parents. Thus, child grows looking at his or her parents and tries to imitate their behavior. It is importance for the parents to understand the fact and behave in a manner that will help these young minds to grasp and inculcate right possessions. Parental involvement is essential for children right from their childhood to schooling and thereafter. (Steinberg, L., Lamborn, S.D. 1992) demonstrate the positive impact of authoritative parenting on adolescent achievement, however, is mediated by the positive effect of authoritativeness on parental involvement in individual's growth. In today's world we have houses with dual career couples have their own career aspirations, but as per investigations such parents tend to gather job stress, family stress, role ambiguity and conflicts (Jaitly, R. et al, 2015) which even affects child behavior. To avoid these stresses the study suggests to have work-life balance (Soi, A. et al, 2011).

\section{METHODOLOGY OF STUDY}

\section{Objective}

This empirical study tries to discover the influence of teachers and universities or educational institutes based on ten value of Schwartz Value Theory helping in developing value based soft skills in budding manager. The research tries to demonstrate 4 C's (Collaboration, Creativity, Communication and Critical Thinking) imparting Values to enhance the performance of young managers in organizations.

\section{Sample Design}

The sample of 200 is collected both through a questionnaire and a field survey. The sample was based on random sampling which consisted of teachers, students and head of institutes. The sample of students and teachers is collected through questionnaires from various B-schools in National Capital Region in India, trying to extract the impact of influence factors on youngsters and indicate the importance of value based pedagogy for impacting value driven soft skills to young managers.

\section{Tools Used}

The data measurement is based on ordinal level where the questionnaires are designed with the help of five point Likert Scale. The data is analyzed using multiple regression method to find out the influence of independent variables (teachers and institutes) on dependent variable (young leaders or students) and also tries to investigate whether $4 \mathrm{C}^{\prime} \mathrm{s}$ are able to deliver Schwartz's Values.

The regression models are presented in the form:

$Y=\beta_{0}+\beta_{1} X_{1}+\beta_{2} X_{2}+\epsilon$

Where, $Y$ represents students (young managers) as a dependent variable.

$\beta_{0}$ is the regression constant

$\beta_{1}, \beta_{2}$ are the partial regression coefficients for the three independent variables. 
$X_{1}, X_{2}$ are the independent variables; teachers, institutes respectively.

$\epsilon$ represents the error of prediction

\section{RESEARCH HYPOTHESIS}

Hypothesis1a: Teachers and Institutes influence student's (young leaders) personality and help them inculcating value driven soft skills.

Table: 1

ANOVA $^{b}$

\begin{tabular}{|ll|c|c|c|c|c|}
\hline \multicolumn{1}{|c|}{ Model } & Sum of Squares & $\mathrm{df}$ & Mean Square & F & Sig. \\
\hline 1 & Regression & .080 & 2 & .040 & .371 & $.692^{\mathrm{a}}$ \\
& Residual & 5.086 & 47 & .108 & & \\
Total & 5.166 & 49 & & & \\
\hline
\end{tabular}

a. Predictors: (Constant), Var3, Var1

b. Dependent Variable: Var2

Coefficients $^{\mathrm{a}}$

\begin{tabular}{|ll|c|c|c|c|c|}
\hline & B & Std. Error & Beta & $\mathrm{t}$ & \multicolumn{1}{c|}{ Sig } \\
\hline 1 & (Constant) & 2.893 & .611 & & 4.737 & .000 \\
& & .021 & .185 & .017 & .116 & .908 \\
& Var1 & .132 & .155 & .123 & .852 & .398 \\
\hline
\end{tabular}

a. Dependent Variable: Var2

\section{Regression equation:}

$\mathrm{Y}$ (students) $=2.893+0.017^{*}$ teachers + $0.123^{*}$ Institutes- - . - . - - (I)

From the above table (table: 1) Var1 signifies influence of Teachers, Var2 indicates influence on students and Var3 represents influence factor institutes. Since, Student is a dependent variable and thereby depends on independent variables teachers and institutes. Regression equation (i) indicates the positive impact of independent variables on the students. As it is clear from the table (Var1 has $\beta_{\mathrm{c}}=$ 0.017, $\mathrm{t}=0.116, \mathrm{p}>0.05),\left(\operatorname{Var} 3\right.$ has $\beta_{\mathrm{c}}=0.123, \mathrm{t}=0.852$, $p>0.05)$. This signifies that the personality of the student is greatly impacted by the culture and value system prevailing in the institutes. Since, institutes are made up of its staff members thus we cannot forget the role of teachers in building the personality of their students. In together, two variables influence the personality of the student in order to impart accurate value system.

In order to understand whether these values (Schwartz's Values) helps in imparting soft skills (Collaboration, Creativity, Communication and Critical Thinking) that can be essential to build good performers and efficient leaders.

Let us consider Hypothesis 1b: 4C's are dependent on Value (Schwartz's Value) based Pedagogy 
Impart on Students

Table: 2

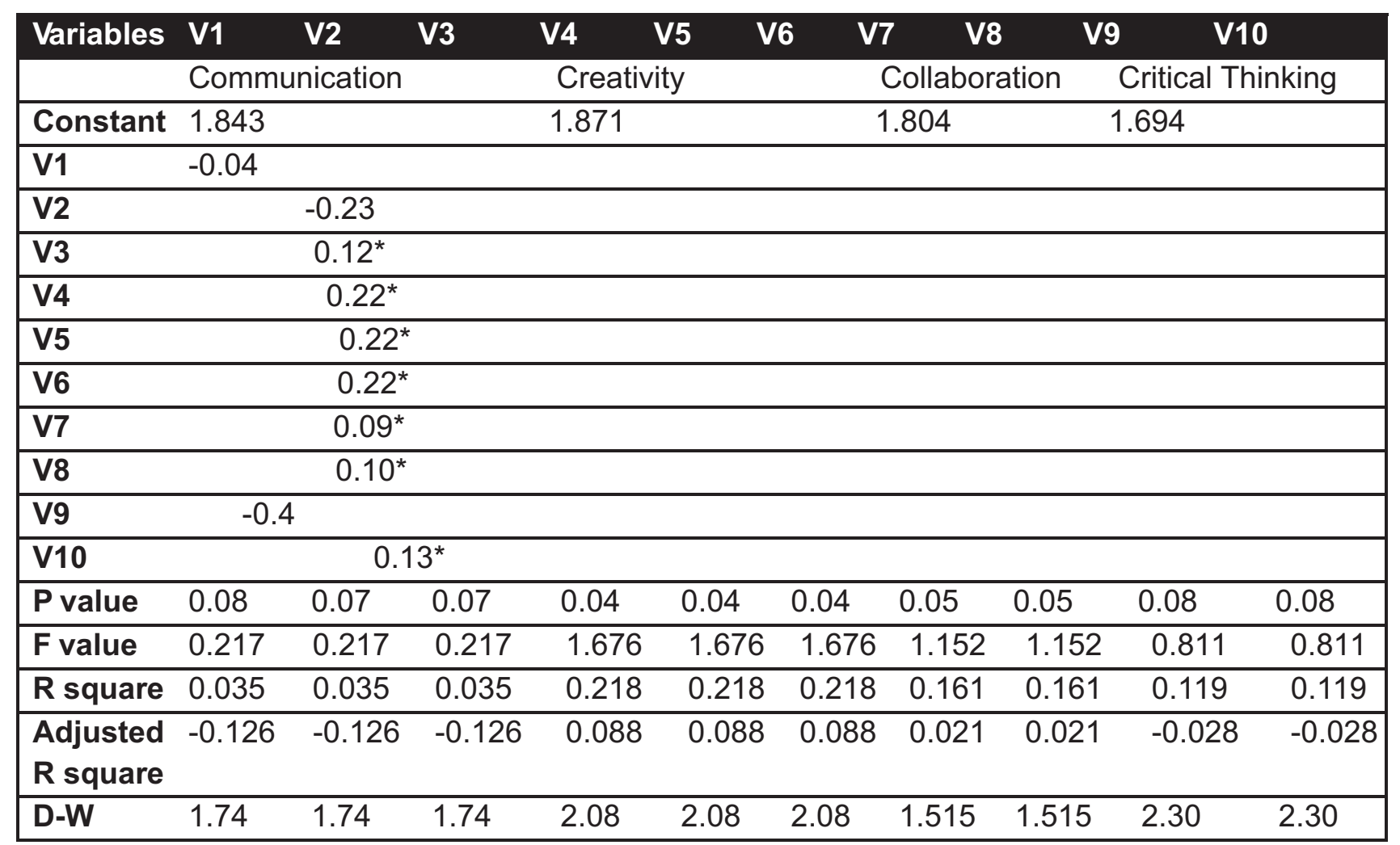

* $\mathrm{P}<0.05$

This indicates values describing communication (as per figure: 1) are not accurately defining the personality of the students (V1 has $\beta_{c}=-0.040$, Adjusted $R^{2}=-0.126$, V2 has $\beta_{c}=-0.233$ Adjusted $R^{2}=$ -0.126 and V3 indicates $\beta_{c}=0.122$, Adjusted $R^{2}=-$ $0.126)$ and the model is not an accurate fit. Although V3 has positive Beta coefficient but adjusted $R^{2}$ is negative which specifies that the model is not an accurate fit. Similarly, V9 and V10 signifies negative value for Beta coefficient and Adjusted $R^{2}$ therefore, this also indicates that V1, V2 and V3 (Power, Security and Conformity respectively) are not significant to Communication, V9 and V10 (that is Tradition and Achievement) are not significant to describe Critical Thinking. Whereas soft skills creativity and collaboration are well associated to values V4: Self Direction, V5: Stimulation, V6: Hedonism and V7: Benevolence, V8: Universal ism and Institutes help in imparting value based soft skills for achieving high performance and becoming good managers at organization.

Delivery by Teachers

Table: 3

\begin{tabular}{|c|c|c|c|c|c|c|}
\hline Variables & V1 & V3 & V5 & V6 & V8 & V10 \\
\hline & Com & unication & Creativity & & Collaboration & Critical Thinking \\
\hline Constant & $\overline{1.94}$ & & 1.655 & & 1.53 & 1.203 \\
\hline V1 & -0.4 & & & & & \\
\hline V2 & & $0.68^{*}$ & & & & \\
\hline V3 & & -0.133 & & & & \\
\hline
\end{tabular}




\begin{tabular}{|c|c|c|c|c|c|c|c|c|c|c|}
\hline V4 & & $0.11^{*}$ & & & & & & & & \\
\hline V5 & & 0.075 & & & & & & & & \\
\hline V6 & & 0.07 & & & & & & & & \\
\hline V7 & & 0.23 & & & & & & & & \\
\hline V8 & & & $85^{\star *}$ & & & & & & & \\
\hline V9 & & & -0.440 & & & & & & & \\
\hline V10 & & & $0.608^{*}$ & & & & & & & \\
\hline$P$ value & 0.02 & 0.02 & 0.02 & 0.08 & 0.08 & 0.08 & 0.01 & 0.01 & 0.008 & 0.008 \\
\hline F value & 1.807 & 1.807 & 1.807 & 0.195 & 0.195 & 0.195 & 1.468 & 1.468 & 3.372 & 3.372 \\
\hline R square & 0.205 & 0.205 & 0.205 & 0.027 & 0.027 & 0.027 & 0.173 & 0.173 & 0.325 & 0.325 \\
\hline $\begin{array}{l}\text { Adjusted } \\
R \text { square }\end{array}$ & 0.092 & 0.092 & 0.092 & 0.112 & 0.112 & 0.112 & 0.055 & 0.055 & 0.229 & 0.229 \\
\hline D-W & 1.85 & 1.85 & 1.85 & 1.89 & 1.89 & 1.89 & 2.28 & 2.28 & 1.87 & 1.87 \\
\hline
\end{tabular}

${ }^{*} \mathrm{P}<0.05$

** $\mathrm{P}<0.01$

Teachers are considered to be training agents who deliver accurate knowledge and values to their students. Table $\mathrm{c}$ indicates V1: Power and V3: Conformity beta coefficient values as negative $\left(\beta_{\mathrm{c}}=\right.$ 0.43 and $\beta_{\mathrm{c}}=-0.133$ ) this signifies these values are not properly delivered to the students whereas more stress is put on delivering creativity and collaboration skills which refers to Self Direction, Stimulation, Hedonism and Benevolence, Universalism respectively $\left(\beta_{c}=0.11, \beta_{c}=0.075\right.$ and $\beta_{c}$ $=0.07)$ and thus, values related to them bears a positive relation and are essential part of pedagogy in build high performing leaders.

\section{CONCLUSION}

From the study it is easily understood that institutes hire efficient resource (teachers) and provides secured and learning environment to these young leaders. Teachers try to impart value driven soft skills with the help of case studies, role plays and other management games. More stress is laid on generating collaborative skills and creativity by teachers.

1. The study reveals that it is necessary for teachers and institutes to work together in an integrated manner to incorporate value driven soft skills in young managers. Teacher and students constantly link values and understand the importance of soft skills to become good leaders.

2. The study also reveals that students can practically use these value driven soft skills which they learn in classrooms at their home, community and workplace.

3. Existing institutes can incorporate these value systems in their pedagogy and train teachers in delivering these values through soft skills which are vital for young managers to achieve high performance at their workplace.

\section{REFERENCES}

1) $13^{\text {th }}$ United Nations Crime Congress on Crime Prevention and Criminal Justice, Doha,12-19 April, 2015, www.un.org/en/events/ crimecongress2015/

2) Alan D., Greenberg, Andrew H. N. (2014), "The Role of Education in Building Soft Skills. October", Wainhouse Research sponsored by SMART.

3) Choudhuri, I. (2005), "Promoting Value Education through Children's Literature" Journal of Value Education, NCERT, January \& July

4) Cubukcu, F. (2014)“Values education through literature in English classes" 5th World 
Conference Educational Sciences - WCES 2013

Procedia - Social and Behavioral Sciences 116265 $-269$

5) Fyffe, L.R. (2006) “An Investigation of Primary School Children with High and Low Values Scores and the Development of an Instrument to Measure Children's Values" Dissertation Report, Griffith University

6) Jaitly, R., Rana, T., Sharma, R. (2015). Work-Life Loyalties: A New Outlook for Dual Career Couples." Effulgence, Vol. 13, No. 1, JanuaryJune ISSN No. 0972-8058

7) Jindal, J. (2013), “Value Based Education -- Need of the Day", September International Journal of Emerging Research in Management \&Technology ISSN: 2278-9359 (Volume-2, Issue9)

8) National education Association, " An Educators guide to four C's" Preparing $21^{\text {st }}$ Century Students for Global Society. wwwnea.org/assets/docs/A-Guide-to-FourCs.pdf

9) Reddy, G.L., Thankachan, T.C.,, Shailaj, M. (2013), "Value Processing Skills Of Secondary School Students With Respect To Their Gender And Religion", Innovative Thoughts International Research Journal ISSN 2321-5453 Volume 1, Issue 1, August.

10) Richerson, P., Mulder, M.B., Vila, B. "Principles Of Human Ecology-Principles for Responsible Management Education: PRME, Six Principles, www.unprme.org

11) Schwartz,S.H. (2006) "An Overview of the Schwartz Theory of Basic Values"
12) Seetha, S. "Necessity of Soft Skills Training for students and professionals" International Journal of Engineering, Business and Enterprise Applications (IJEBEA) ISSN (Print)- 2279-0020, ISSN (Online)- 2279-0039

13) Seshadri, C. (2005), "An Approach to Value Orientation of Teachers' Education", Journal Of Value Ducation January \& July

14) Sharma, S., Garg, S., Mittal, S. (2015), "Empowering Youth by Value Based Education: A Conceptual Framework" Broombury Publications, University School of Management Studies, Indraprastha University (February) ISBN: 978-93-84898-78-6 (Printed copies for internal circulation).unprme.org/

15) Singh, A. "Evaluating the Impacts of Value Education: Some Case Studies", International Journal of Educational Planning \& Administration Volume 1, Number 1, pp. 1-8

16) Soi, A., Agrawal, A., Massey, S. (2011). WorkLife Balance. Effulgence, Vol. 9, No. 2, JulyDecember. ISSN No. 0972-8058

17) Srivastava, A. (2013), "Value Education: Past and Present" Voice of Research Vol. 2, Issue 3 December ISSN No. 2277-7733

18) Steinberg, L., Lamborn, S.D., Dornbusch, S.M., Darling, N. "Impart of Parenting Practices on Adolescence Achievement, Authoritative Parenting, Schools Involvement and Encouragement to succeed Child Development, $1992,63,12661-1281$ 